УДК 351.778

\author{
Литвиновський Свген, \\ канд. пед. наук, \\ старш. наук. співроб., \\ ORCID iD 0000-0003-2127-8354 \\ E-mail: doklytvynovsky@ukr.net \\ Литвиновська Ірина, \\ канд. пед. наук, \\ ORCID iD 0000-0002-1846-8627 \\ E-mail: Irynalitva@ukr.net
}

\title{
ФЕНОМЕН ЛІДЕРСТВА НА ДЕРЖАВНІЙ СЛУЖБІ
}

\section{https://doi.org/10.32689/2618-0065-2021-1(7)-162-179}

\begin{abstract}
Анотація. Феномен лідерства вивчається протягом багатьох років великою кількістю вчених. Дослідження деяких 3 них, дотичних до теми статті, аналізуються в ній. Враховуючи, що природа феномену лідерства надзвичайно складна, носить індивідуально-суспільний характер в статті визначається, що лідерство - це унікальна синергія: природнього-генетичних (Богом даних) задатків; материнського (батьківського) виховання; сприятливого соціального середовища (оточення, у тому числі і освітнього, як ціннісно-формувального стрижня соціуму); власної функціональності особистості професіонала. Функціональність визначається набутим досвідом, свідомо чи несвідомо сформованими уміннями, навичками, якостями. В статті аналізуються деякі підходи до визначення феномена лідерства. Визначено, що найбільш усталеними теоріями вважаються харизматична та синтетична теорія, «теорія рис», а також ситуаційний та поведінковий підхід. Акцентується увага, що для державної служби цікавими є інструментальне й емоційне лідерство, два важливих нових концепти лідерства: «Т-модель» та «Лідер-каталізатор». Державна служба повинна бути спрямована на «суспільне благо, на інтереси й потреби інших людей та їх задоволення тільки за умови дотримання правових і моральних обмежень». В статті робиться висновок, що феномен Лідерства являє собою феномен, породжений системою неформальних, неофіційних відносин між людьми. Воно природним чином виникає в будь-якій групі на підгрунті впливу особистісного авторитету лідера на взаємини й поводження інших людей. Роль лідера виникає стихійно, штатним розкладом організації вона не передбачається. Лідерство - це надкомпетентність особистості, у тому числі i керівника, яку важко виміряти та важко відтворити. Подальшим науковим завданням визначається гіпотетичний пошук переліку особистісних та професійних якостей, які із простої людини роблять керівника-лідера державної служби.
\end{abstract}

Ключові слова: феномен лідерства, державна служба, ситуаційне та емоційне лідерство, Т-лідерство, природньо-генетичні задатки, соціальне середовище, батьківське виховання. 


\section{Науковий вісник : Державне управління №1 (7) 2021}

Постановка проблеми. До питання аналізу проблем лідерства на державній службі ми вже не вперше звертаємося [1-3].

Управлінське лідерство або лідерство управлінця - одна із проблематик розв'язання проблем лідерства в цілому. Глибина розв'язання проблеми управлінського лідерства полягає у вирішенні, на перший погляд, простого питання - якими унікальними здатностями повинен володіти керівник, щоб бути одночасно лідером організації, який ефективно організовує iї діяльність. Як визначити ці якості та яким чином їх розвивати.

Погоджуючись 3 О. Пономарьовим в тому, що природа феномену лідерства надзвичайно складна, носить індивідуальносуспільний характер [4], визначаємо (С. Литвиновський), що лідерство - це унікальна синергія: природнього-генетичних (Богом даних) задатків; материнського (батьківського) виховання; сприятливого соціального середовища (оточення, у тому числі і освітнього, як ціннісно-формувального стрижня соціуму); власної функціональності особистості професіонала. Функціональність визначається набутим досвідом, свідомо чи несвідомо сформованими уміннями, навичками, якостями.

Лідерство - це надкомпетентність особистості, у тому числі і керівника, яку важко виміряти та важко відтворити. Дві особистості, два лідера - це неоднакові набори знань, навичок, умінь, якостей. Це два унікальних поєднання зазначених вище факторів, які формують функціональність професіонала, який здатний ефективно створювати (бачення, мислення), організовувати (харизма), керувати i досягати результатів діяльності.

Постає запитання? Враховуючи специфіку розподілу праці на державній службі від формування політики до адміністративноінформаційного забезпечення, чи всі державні службовці повинні бути лідерами? Наприклад, в порівнянні з футболом. Хто досягає успіху? Команда зірок (потенціальних лідерів (формування політики, стратеги)) чи зіркова команда (команда професіоналів, де є лідер (стратег), його послідовники (операційники, аналітики тощо), генератори ідей, виконавці рутинної роботи). До речі, в 


\section{Науковий вісник : Державне управління №1 (7) 2021}

даному сенсі, цікавим дослідженням було вивчення взаємовідносин державної служби на основі теорії ігор [5].

Але це напрям подальшого дослідження умов сприятливого соціального середовища (оточення, у тому числі і освітнього, як ціннісно-формувального стрижня соціуму) на формування лідерства у конкретній ситуації. $\mathrm{y}$ даній публікації ми зупинимось на викладі власних думок щодо лідерства в цілому та лідерства на державній службі на основі аналізу джерельної бази наукових досліджень 3 питань лідерства, включеного пролонгованого спостереження за діяльністю керівників різних органів виконавчої влади, закладів вищої освіти.

Феномен лідерства в державній службі (політичній владі) заслуговує ретельного дослідження. Ж. Блондель зазначав, що для цього «необхідно зайнятися аналізом великої групи лідерів, що користуються значним впливом, з обліком їхньої стартової позиції й зовнішніх умов. У цьому зв'язку важливо більше знати насамперед про психологічні якості лідерів стосовно до даної ситуації. Також важливо виявити інституціональні механізми, які «оркеструють» потенційний вплив лідерів, допомагаючи перетворювати мету в політичні кроки, поліпшуючи зв'язок лідера 3 населенням, і навпаки. Ось чому, детальне вивчення впливу політичних лідерів (керівників державних установ), їхніх якостей $\epsilon$ чимось більшим, ніж задоволення простої зацікавленості щодо поведінки людей, що керують світом.

Це завдання прямо й нерозривно пов'язане зі спробою забезпечити умови, в яких політичне лідерство буде вдосконалюватися з покоління в покоління» [6].

Як бачимо, вивчення ознак і характерних рис лідерства в державній службі - це наукові дослідження і не одного наукового інституту.

У нашій роботі ми зупинимось на дотичному джерельному пошуку останніх досліджень і публікацій, узагальненні деяких підходів до феномена лідерства, виокремлення деяких психологічних новоутворень особистості, які, на нашу думку, саме створюють феномен лідерства, формують ту функціональність керівника-лідера, яку складно виміряти, але 


\section{Науковий вісник : Державне управління №1 (7) 2021}

вочевидь видно за результатами діяльності - «істотну значущість для забезпечення процесів нормального функціонування та розвитку соціуму і міжособистісних взаємовідносин, а також для розв'язання можливих суперечностей і конфліктів» [7].

Аналіз останніх досліджень і публікацій. Джерельний пошук в каталогах Національної бібліотеки імені B. I. Вернадського за ключовим словом «лідер...» надає 338 посилань з 1996 року (станом на 10.10.2020) [8].

Серед джерел, питанням лідерства на державній службі у прямій постановці проблеми присвячена наукова праця Т. Підлісної [9].

Дотично питання лідерства на державній службі торкаються науковці НАДУ, що досліджували проблеми формування еліт, кадрової політики тощо (О. Пархоменко-Куцевіл, О. Піддубчак, В. Побережна, Н. Попадюк, П. Сидоренко, І. Сурай) [10-15].

У 2014 році науковцями НАДУ створений науковобібліографічний покажчик «Лідерство, управлінська еліта в сучасних умовах державотворення» [16].

Також проблемі лідерства на державній службі присвячена низка навчально-методичних та довідникових праць [17-21].

Окремо питанням лідерства було присвячено загальновідомі щорічні Рішельєвські академічні читання [22].

Зрозуміло, що в Національній бібліотеці України наявні i світові бестселери з питань лідерства, які повинні були б стати настільними книгами топ-менеджменту державної служби, рекомендовані для опрацювання слухачами, які опановують освітню програму на здобуття бакалавра (магістра) за спеціальністю «Публічне управління та адміністрування», наразі за спеціалізацією «Державне управління у сфері цивільного захисту». Саме читання формує мислення лідера. Серед них праці Джона Тіздейла, Джефрі Хьюза [23], Джима Ланкастера [24], Іцхака Адізеса [25], Джона Максвела [26].

Зазначені джерела можуть бути теоретичним підгрунтям компаративного аналізу феномену лідерства на державній службі. 


\section{Науковий вісник : Державне управління №1 (7) 2021}

У розрізі розв'язання проблеми розвитку лідерства на державній службі нашу увагу привернула праця О. Пономарьова та ін. [4]. Соціально-важливі якості лідерства на державній службі та саму ідею служіння своєму народу підтверджує саме думка автора щодо його морального сенсу. «Моральнісний сенс лідерства полягає перш за все у його спрямованості на суспільне благо, на інтереси й потреби інших людей та їх задоволення тільки за умови дотримання правових і моральних обмежень. Важливим аспектом є й те, що справжній лідер повинен бути для своїх прихильників та інших людей взірцем моральності, порядності й відповідальності. Відданість справі, вірність слову й особиста скромність $€$ не просто його атрибутивними характеристиками у відносинах 3 людьми. Вони виступають проявами його власних моральнісних принципів і переконань, які він демонструє сам і прагне прищепити тим, 3 ким йому доводиться працювати чи навіть просто спілкуватися» [7].

У короткому висловлюванні автора нібито закладено положення про місію державної служби, етику державного службовця. Те, чим повинен володіти не тільки керівник-лідер, а й пересічний громадянин України - моральності, порядності й відповідальності, а державна служба повинна бути спрямована на «суспільне благо, на інтереси й потреби інших людей та їх задоволення тільки за умови дотримання правових і моральних обмежень» [7].

Автори проекту «Реформа управління персоналом на державній службі в Україні» розвиток лідерства розглядають передумовою «визнання і підтримки державної служби як конкурентоспроможного, привабливого місця праці, здатного привернути та утримати найкращі кадри, кваліфікованих працівників (workplace of choice). Така концепція зумовлює i основні підходи до управління людьми на державній службі, які мають сприяти забезпеченню успіху та впевненого майбутнього для державної служби. Державна служба є зацікавленою, аби на ній працювали справжні лідери, віданні своїй справі служінню громадськості, спроможні відповідати викликам часу та працювати у складних динамічних умовах» [27, с. 22]. 


\section{Науковий вісник : Державне управління №1 (7) 2021}

У попередніх своїх роботах [1-3] ми зазначали, що характерною рисою сьогодення - $\epsilon$ захопленість лідерством. Джерел з проблематики лідерства і наукової, і публіцистичної, i бізнесової - надлишок. Наприклад, в книзі «Handbook of Leadership» [28] список використаних джерел складає більш 9 тисяч посилань. Що казати тоді про Інтернет-пошук або пошук наукометричними базами, наприклад «Skopus».

Найбільша пошукова система «Google» за вибірковим запитом «лідерство на державній службі» надає 2300 посилань (станом 12.02.2021). Ми обрали декілька 3 них, які стосуються нашого дослідження.

У рамках нашого викладу зацікавлення представляють наукові праці, зокрема науковця НАДУ Р. Сторожука, який вивчав стан дослідженості проблеми лідерства [29], С. Чернова, C. Гайдученка [30], авторів проекту «Реформа управління персоналом на державній службі України» [27], О. Романовського [31].

Деякі положення цих праць ми використаємо в подальшому для обгрунтування власного бачення феномена лідерства.

Мета статті. Як зазначалось, в даній публікації презентуємо виклад власних думок щодо феномена лідерства в цілому та лідерства на державній службі на основі аналізу джерельної бази наукових досліджень 3 цієї проблематики, включеного пролонгованого спостереження за діяльністю керівників різних органів виконавчої влади, закладів вищої освіти.

Методи дослідження. Методами дослідження були: критичний аналіз попередніх досліджень 3 метою визначення власного розуміння феномена лідерства; інтернет-опитування за проблематикою дослідження. Для проведення останнього складений опитувальник на базі сервісу «Google Forme» (обгрунтування змісту опитувальника, кількість респондентів, а також результати опитування та їх математичну обробку буде подано в наступних публікаціях).

Виклад основного матеріалу. Існує багато теорій, які прагнуть пояснити сутність феномена лідерства та його походження. Ці теорії набули особливого значення, коли 
розпочалася цілеспрямована підготовка професійних керівників, яким бажано набувати власної функціональності для забезпечення належної результативності керівної діяльності на основі формування тих чи інших необхідних якостей.

Найбільш усталеними теоріями вважаються харизматична та синтетична теорія, «теорія рис» [31]. Їх сутність ми розкривали у своїх попередніх публікаціях [1-3].

Важливо відзначити такий характерний атрибут феномену лідерства, як те, що лідер не просто веде людей за собою, а й хоче вести їх, тоді як самі люди, його послідовники не просто йдуть за лідером, а й хочуть йти за ним.

Для розкриття сутності феномена лідерства на державній службі важливим нам здається врахування сутності двох можливих його стилів (Ф. Фідлер): інструментальне лідерство (орієнтація на завдання) й емоційне лідерство (орієнтація на міжособистісні відносини) [32]. Зрозуміло, що двох окремих (чистих) стилів в практичній діяльності не існує, а синергетичне поєднання їx і створює унікальну функціональність лідера на державній службі. Хтось більше орієнтований на емоції, а хтось на інструментальність. Однак в обох випадках визнається лідером той, який ефективно впливає на продуктивність діяльності. Не випадково у своєму розвитку теорія Ф. Фідлера в подальшому при визначенні сутності лідерства враховує рівень розвитку інтелекту, здатність до координації й співробітництва членів групи та рівень сумісності членів групи.

Для визначення лідерства на державній службі доречна до використання мотиваційна теорія лідерства, досить відома у США. Представники теорії С. Мітчел, С. Еванс і ін. [33, с. 222]) стверджують, що ефективність лідера корелює із ступенем впливу на мотивацію співробітників; рівень продуктивності виконання ними завдань. Важливим показником $\epsilon$ рівень задоволеності послідовників лідера процесом і результатами сумісної діяльності.

Представники цієї теорії визначають типи лідерської поведінки: директивне лідерство (більш притаманне сучасній державній службі (за нашими спостереженнями); підтримуюче 


\section{Науковий вісник : Державне управління №1 (7) 2021}

лідерство (лідерство необхідне для розвитку сервісної функції державної служби); лідерство, орієнтоване на досягнення ефективного результату (впроваджується в теперішню діяльність державної служби на основі декомпозиції завдань від керівника до підлеглого та визначення показників ii ефективності, результативності). Ця теорія також стверджує, що феномен лідерства неможливий без врахування відповідних установок й поведінки послідовників, на підставі визначення рівня їх задоволеності діяльністю, ступеню схвалення дій лідера, мотивації поведінки.

Визначення в цій теорії важливості у формуванні лідерства ситуативних факторів (індивідуальні риси лідера і послідовників (Богом дані задатки); фактору «навколишнього середовища» (декомпозиція завдань, система розподілу повноважень й т.і.), підтверджує нашу гіпотезу, що феномен лідерства синергетично поєднує природньо-генетичні (Богом даних) задатки та вплив сприятливого соціального середовища на формування функціональності лідера.

На сьогодні експерти виділяють два важливих нових концепти лідерства: «Т-модель» та «Лідер-каталізатор».

$T$-модель. Це фахівець, який володіє глибокими знаннями, уміннями та досвідом в певній предметній галузі та широким набором додаткових компетентностей. Це експерт, який володіє функціональною або технічною експертизою; роками відмінно виконує одну і ту ж роботу, його складно замінити, на нього можна покластися, йому можна довіряти; він отримує визнання в організації; вміє працювати автономно. Водночас, він гнучкий в навчанні: легко освоює нові функції; добре робить роботу, з якою вперше стикається; вирішує складні (нові) проблеми; міркує стратегічно, володіє широким баченням; добре працює в умовах невизначеності і складності; приймає зміни; має різноманітні інтереси; швидкий та нетерплячий, не поважає status quo.

Лiдер-каталізатор (catalyst). Нова рольова модель менеджера - це менеджер, який в складних умовах може підтримати і діяльність, і команду. Так звана жіноча модель управління, яка включає розуміння, турботу, підтримку та 
допомогу в розвитку. За такої ситуації лідером стає не головний експерт, а «мамочка», яка може забезпечити безпечне середовище для роботи експертів. Міжособистісні стосунки та емоції - це, на думку Джері Туммера та Крейга Колдвела, не головна справа лідерів-каталізаторів, але все рівно вони $є$ першими, хто намагається допомогти розв'язати проблемну ситуацію, сприяють розв'язанню конфліктів в команді [34]. Також зазначені автори звертають увагу на такі ролі лідера в цій концепції як наставництво та коучинг. Якщо менеджер освоїв основні компетентності, то також повинен допомагати іншим їх розвивати. Так зване масштабування компетентності.

Аналіз зазначених вище концептів свідчить, що в реальній діяльності існують їх синергія, «мікс», який важко виміряти, однак який, як раз, і дозволяє керівнику-лідеру досягти той функціональності, яка формує і команду, і досягати результатів.

У науковій літературі точиться полеміка щодо дотичності (розбіжності) феноменів «керівництво» та «лідерство». I хто потрібний сучасній державній службі - керівник, лідер, чи керівник-лідер. Чи може простий головний спеціаліст може бути неформальним лідером, а завдання керівника - вміло використовувати такий людський ресурс.

Практика професійної діяльності свідчить, що керівник організації не завжди є лідером, а лідер - не завжди керівником. Наукові дослідження стверджують, що краще, аби керівник був лідером.

С. Чернов, С. Гайдученко [30] вважають, що визначальним результатом генези організаційної культури в публічному управлінні, на формування нового типу якого постійно звертає увагу Національне агентство державної служби України, на даному етапі ії розвитку є синтез ролей керівника та лідера. Якщо на попередніх етапах ключовою управлінською проблемою була задача встановлення конструктивного співробітництва між офіційними керівниками з одного боку, і лідерами робочих груп та трудових колективів 3 іншого, то в даний час стає нормою в діяльності успішного управлінця - суміщення функцій керівника i лідера. Внаслідок цього поняття керівництва поступово 


\section{Науковий вісник : Державне управління №1 (7) 2021}

змінюється поняттям лідерства, оскільки реальне та ефективне управління організацією забезпечується не стільки авторитетом посади, скільки авторитетом особистості керівника, його лідерськими здібностями. Отже, лідерські якості керівника стають аксіомою успішного формування та розвитку сучасної організаційної культури. Не випадково Е. Шейн у своій роботі тлумачить лідерство як управлінський вплив, керівництво, що здійснюється завдяки цінним особистісним якостям. У зв'язку 3 цим, Е. Шейн пише: «Створення культури, іiі еволюція та управління нею - ось у чому полягає достеменне завдання керівника» [цит. за 30, с. 16].

Однак між поняттями керівник і лідер є свої розбіжності. Нажаль, протягом своєї державної служби в декількох органах влади зустрічали більше навіть не керівників, а адміністраторів 3 тоталітарно-авторитарним стилем керівництва, не кажучи вже про лідерство. Лідер - не той, хто веде, а той, за яким хочуть йти.

Висновки та напрями подальших досліджень. Отже, Лідерство являє собою феномен, породжений системою неформальних, неофіційних відносин між людьми. Воно природним чином виникає в будь-якій групі на підгрунті впливу особистісного авторитету лідера на взаємини й поводження інших людей.

Лідерство на державній службі мало вивчений феномен, який вимагає комплексного міждисциплінарного пролонгованого дослідження. Лідерство керівника державної служби визначається сучасним атрибутом організаційної культури публічного управління.

Феномен лідерства полягає в тому, що роль лідера виникає стихійно, штатним розкладом державного органу вона не передбачається. Керівник державної служби нерідко призначається на свою посаду й обіймає ії незалежно від того, сприймають чи не сприймають його підлеглі відповідним цій ролі.

Порівнюючи феномени лідерства та керівництва в рамках класичного менеджменту та лідерства, на підставі дослідження $[27$, с. 20] можна стверджувати, що Лідерство передбачає вміння 


\section{Науковий вісник : Державне управління №1 (7) 2021}

вести працівників за собою до спільної мети, наснажувати працівників, аби вони самі хотіли робити те, що необхідно. Тобто лідер створює сприятливе соціальне середовище для комфортного перебування співробітників, одночасно - їх продуктивної діяльності.

Відношення керівника до підлеглих в класичному менеджменті - «Я і мої працівники (солдатики)», в лідерстві «МИ», «Наша команда».

Ми визначаємо, що лідерство - це унікальна синергія: природнього-генетичних (Богом даних) задатків; материнського (батьківського) виховання; сприятливого соціального середовища (оточення, у тому числі і освітнього, як ціннісно-формувального хребта соціуму); власної функціональності особистості професіонала. Функціональність визначається набутим досвідом, свідомо чи несвідомо сформованими уміннями, навичками, якостями.

Лідерство - це надкомпетентність особистості, у тому числі і керівника, яку важко виміряти та важко відтворити.

Які ж особистісні та професійні якості, які із простої людини роблять керівника-лідера? Чи існує той геній - керівник (лідер), на основі вивчення діяльності якого можна встановити репертуар якостей, творіння яких у суспільстві допоможуть йому вийти із кризи і досягти «ери всезагального блага». На ці питання ми спробуємо відповісти у ході наших подальших досліджень і присвятимо цьому наступну окрему публікацію.

\section{Список використаних джерел}

1. Шляхи удосконалення професійної освіти військової еліти. Проблеми та перспективи формування національної гуманітарно-технічної еліти: Зб. наук. пр.: У 2-х ч. Х: НТУ “ХПІ”. 2002. Вип. 2. Ч. 2. C. $371-375$.

2. Теоретичні та організаційно-методичні засади проектування освітньої діяльності навчально-методичних установ цивільного захисту : монографія. / Бегун В. В.; За заг. ред. Литвиновський С. Ю. та ін. Львів: Ліра, 2017. 230 с.

3. Литвиновська I. А. Ознаки та характерні риси лідера в організації. Індивідуально-практичне завдання. ЛРІДУ НАДУ, 2011. 25 с. 


\section{Науковий вісник : Державне управління №1 (7) 2021}

4. Моральнісний сенс філософії лідерства : навч.-метод. посіб. / О.С. Пономарьов та ін. Нац. техн. ун-т "Харків. політехн. ін-т". Харків : НТУ "ХПІ" : Панов А. М. [вид.], 2020. 119 с.

5. Нейман Дж. фон, Моргенштерн О. Теория игр и экономическое поведение. М.: Наука, 1970 (англ. Theory of Games and Economic Behaviour, 1944).

6. Blondel J. Political Leadership: Towards a General Analysis. - London Beverly Hills - New Delhi: SAGE Publications, 1987. [Политическое лидерство: Путь к всеобъемлющему аналізу] М., 1992. 135 с. URL : http://grachev62.narod.ru/blondel/ch_1.htm\#ch103 (дата звернення: 10.10.2020).

7. Пономарьов О. С. Феномен лідерства як об'єкт дослідження філософії управління // Репозитарій НТУ «ХПІ» / НТУ «ХПІ», м. Харків. URL : http://repository.kpi.kharkov.ua/bitstream/KhPIPress/22977/1/Ponomariov Fenomen 2015.pdf (дата звернення: 10.10.2020).

8. Пошукова система «Лідер...»//Електронний каталог Національної бібліотеки імені Вернадського. URL: http://irbis-nbuv.gov.ua/cgibin/irbis_all/cgiirbis_64.exe (дата звернення 10.10.2020).

9. Підлісна Т. В. Лідерство в державній службі України: теоретичні основи : дис. ... канд. наук з держ. упр. : 25.00.03. Ін-т законодавства Верховної Ради України. К., 2012. 272 с.

10. Пархоменко-Куцевіл O. I. Теоретико-методологічні засади формування, розвитку та модернізації системи державних посад : автореф. дис. ... д-ра наук з держ. упр. Харків. регіон. ін-т держ. упр. Нац. акад. держ. упр. при Президентові України. Х., 2012. 35 с.

11. Піддубчак О. А. Соціалізація молодих політико-управлінських кадрів на державній службі в умовах суспільної трансформації в Україні : автореф. дис. ... канд. наук з держ. упр. Нач. акад. держ. упр. при Президентові Украӥни. К., 2013. 20 с.

12. Побережна В. А. Формування та реалізація державної кадрової політики у сфері державної служби України : автореф. дис. ... канд. наук з держ. упр. Наи. акад. держ. упр. при Президентові Украӥни. K., 2014. 20 c.

13. Попадюк H. I. Механізми формування державно-управлінської еліти: вітчизняний та зарубіжний досвід : автореф. дис. ... канд. наук з держ. упр. Наи. акад. держ. упр. при Президентові України. К., 2013. $20 \mathrm{c}$.

14. Сидоренко П. В. Кадрова політика в місцевих органах виконавчої влади України: сутність та тенденції розвитку : автореф. дис. ... канд. наук з держ. упр. Наи. акад. держ. упр. при Президентові України. К., 2012. 20 с. 


\section{Науковий вісник : Державне управління №1 (7) 2021}

15. Сурай I. Г. Формування й розвиток еліти в державному управлінні України : автореф. дис. ... д-ра наук з держ. упр. Наи. акад. держ. упр. при Президентові Украӥни. К., 2014. 36 с.

16. Лідерство, управлінська еліта в сучасних умовах державотворення: науково-бібліографічний. покажчик / Відділ інформаційнобібліотечного забезпечення. К.: НАДУ, 2014. URL: https://cutt.ly/AjO9CvE (дата звернення 10.10.2020)

17. Якубовський О. П., Приходченко Л. Л. Кадри, еліти, лідерство в державному управлінні : навч.-метод. посібник. О. : ОФ УАДУ ; О. : Оптімум, 2001. $173 \mathrm{c}$.

18. Михненко А. М., Гончарук Н. Т., Макаренко Е. М. Лідерство та управлінська еліта : навч. посіб. К. : НАДУ, 2012. 291 с.

19. Пірен Марія. Лідерство: сутність та реалізація в українському суспільстві : навч. посіб. для студ. вищ. навч. закл. К. : Університет "Україна", 2012. 231 с.

20. Лідерство в місцевому самоврядуванні : слов. термінів / уклад. та ред.: Гошовська В. А. та ін. Харків : Фактор, 2015. 155 с.

21. Лідерство в системі державної служби : навч. посіб. / Іжа М. та ін. Одеса : ОРІДУ НАДУ, 2013. 130 с.

22. Лідерство в державному управлінні : зб. доп. щоріч. Рішельєв. акад. читань (21-23 верес. 2011 р., м. Одеса). О., 2012. 268 с.

23. Тіздейл Джон, і Хьюз Джефр Ефективне лідерство та менеджмент : практ. посіб. О. : Фенікс, 2013. 140 с.

24. Ланкастер Джим. Лідерство в стилі Lean. Шлях до постійного вдосконалення вашого бізнесу : [пер. 3 англ.] The work of management: a daily path to sustainable improvement / Jim Lancaster./. Київ : Фенікс, 2017. 238 с.

25. Адізес Іцхак. Командне лідерство. Як порозумітися з будь-яким менеджером [Leading the leaders: how to enrich your style of management and handle people whose style is different from yours / Ichak Adizes. Santa Barbara, 2004]. Київ : Наш формат, 2019. 312 c.

26. Максвелл Джон. 21 беззаперечний закон лідерства [пер. 3 англ. Т. Фролов ; передм. Стівена Р. Кові]. [The 21 irrefutable laws of leadership: follow them and people will follow you / John C. Maxwell. Nashville, 2007]. 2-ге вид. Харків : Клуб Сімейного Дозвілля, 2019. $319 \mathrm{c}$.

27. Бізо Л., Ібрагімова І., Кікоть О., Барань Є. та ін. Розвиток лідерства. К. : Проект «Реформа управління персоналом на державній службі в Україні», 2012. $400 \mathrm{c.}$

28. The Bass Handbook of Leadership: Theory, Research, and Managerial Applications. URL: https://books.google.com.ua/books?id=dMMEnnOJQMC\&printsec $=$ frontcover\&redir_esc $=\mathrm{y} \# \mathrm{v}=$ onepage $\& \mathrm{q} \& \mathrm{f}=\mathrm{false}$ (дата звернення 10.10.2020). 


\section{Науковий вісник : Державне управління №1 (7) 2021}

29. Сторожук Р.І. Стан дослідження проблеми лідерства у вітчизняній та зарубіжній літературі. Держава та регіони. Серія Державне управління, 2017. №3. С. $21-25$.

30. Чернов С. І., Гайдученко С. О. Вплив лідерства на формування та розвиток організаційної культури в публічному управлінні. Ефективність державного управління. 2014. Вип. 40. С. 109 - 115. URL: http://nbuv.gov.ua/UJRN/efdu_2014_40_15 (дата звернення 10.10.2020)

31. Романовський О. Г., Гура Т. В., Книш А. Є., Бондаренко В. В. Теорія і практика формування лідера : навч. посіб. 2017 p. 100 с.

32. Фідлер Ф. Про моделі керівництва. URL: http://pidruchniki.com.ua/19310710/menedzhment/modeli_keruvannya. (дата звернення: 10.10.2020).

33. Бозаджиев В. Л. Политическая психология: учеб. пособ. М., 2015. $474 \mathrm{c}$.

34. Jerry Toomer, Craig Caldwell The Catalyst Effect: 12 Skills and Behaviors to Boost Your Impact and Elevate Team Performance. Emerald Publishing Limited, 2018 - 255 p.

\section{References}

1. Lytvynovskyi Ye.Iu. (2002) Shliakhy udoskonalennia profesiinoi osvity viiskovoi elity. [Ways to improve the professional education of the military elite]. Problemy ta perspektyvy formuvannia natsionalnoi humanitarno-tekhnichnoi elity: $\mathrm{Zb}$. nauk. pr.: U 2-kh ch. Kh: NTU "KhPI". Vyp. 2. Ch. 2. S. $371-375$ [in Ukrainian].

2. Lytvynovskyi Ye.Iu ta in. (2017) Teoretychni ta orhanizatsiinometodychni zasady proektuvannia osvitnoi diialnosti navchalnometodychnykh ustanov tsyvilnoho zakhystu : monohrafiia. [Theoretical and organizational-methodical bases of designing of educational activity of educational-methodical establishments of civil protection: monograph]. / Lytvynovskyi Ye.Iu. Lviv: Lira. 230 s. [in Ukrainian].

3. Lytvynovska I. A. (2011) Oznaky ta kharakterni rysy lidera v orhanizatsii. [Signs and characteristics of a leader in the organization. Individualpractical task]. Indyvidualno-praktychne zavdannia. LRIDU NADU. $25 \mathrm{~s}$. [in Ukrainian].

4. Ponomarov O. S. ta in. (2020) Moralnisnyi sens filosofii liderstva : navch.-metod. posib. [The moral meaning of the philosophy of leadership] / Nats. tekhn. un-t "Kharkiv. politekhn. in-t". Kharkiv : NTU "KhPI" : Panov A. M. [vyd.]. 119 s. [in Ukrainian].

5. Neiman Dzh. fon, Morhenshtern O. (1970) Teoryia yhr y ekonomycheskoe povedenye. [Theory of Games and Economic Behaviour]. M.: Nauka. [in Rushian]. 


\section{Науковий вісник : Державне управління №1 (7) 2021}

6. Blondel J. (1992) Political Leadership: Towards a General Analysis. London. Beverly Hills. New Delhi: SAGE Publications, 1987. [Polytycheskoe lyderstvo: Put k vseobъemliushchemu analizu]. $135 \mathrm{~s}$. URL : http://grachev62.narod.ru/blondel/ch_1.htm\#ch103 (data zvernennia: 10.10.2020) [in English].

7. Ponomarov O. S. (2015) Fenomen liderstva yak obiekt doslidzhennia filosofii upravlinnia. [The phenomenon of leadership as an object of study of management philosophy] // Repozytarii NTU «KhPI» / NTU «hhPI», $\mathrm{m}$.

Kharkiv.

URL:

http://repository.kpi.kharkov.ua/bitstream/KhPI-

Press/22977/1/Ponomariov_Fenomen_2015.pdf (data zvernennia: 10.10.2020) [in Ukrainian].

8. Poshukova systema «Lider...». [Search system "Leader]. //"//Elektronnyi kataloh Natsionalnoi biblioteky imeni Vernadskoho. URL: http://irbisnbuv.gov.ua/cgi-bin/irbis_all/cgiirbis_64.exe (data zvernennia 10.10.2020) [in Ukrainian].

9. Pidlisna T. V. (2012) Liderstvo v derzhavnii sluzhbi Ukrainy: teoretychni osnovy : dys. ... kand. nauk z derzh. upr. : 25.00.03. [Leadership in the civil service of Ukraine: theoretical foundations]; In-t zakonodavstva Verkhovnoi Rady Ukrainy. K., 2012. 272 s. [in Ukrainian].

10. Parkhomenko-Kutsevil O. I. (2012) Teoretyko-metodolohichni zasady formuvannia, rozvytku ta modernizatsii systemy derzhavnykh posad : avtoref. dys .... d-ra nauk z derzh. upr. Kharkiv. rehion. [Theoretical and methodological principles of formation, development and modernization of the system of state positions]. in-t derzh. upr. Nats. akad. derzh. upr. pry Prezydentovi Ukrainy. Kh. 35 s. [in Ukrainian].

11. Piddubchak O. A. (2013) Sotsializatsiia molodykh politykoupravlinskykh kadriv na derzhavnii sluzhbi $\mathrm{v}$ umovakh suspilnoi transformatsii v Ukraini [Socialization of young political and managerial personnel in the civil service in terms of social transformation in Ukraine] : avtoref. dys. ... kand. nauk z derzh. upr. Nats. akad. derzh. upr. pry Prezydentovi Ukrainy. K. 20 s. [in Ukrainian].

12. Poberezhna V. A. (2014) Formuvannia ta realizatsiia derzhavnoi kadrovoi polityky u sferi derzhavnoi sluzhby Ukrainy [Formation and implementation of state personnel policy in the field of civil service of Ukraine] : avtoref. dys. ... kand. nauk z derzh. upr. Nats. akad. derzh. upr. pry Prezydentovi Ukrainy. K. 20 s. [in Ukrainian].

13. Popadiuk N. I. (2013) Mekhanizmy formuvannia derzhavno-upravlinskoi elity: vitchyznianyi ta zarubizhnyi dosvid [Mechanisms of formation of the state-administrative elite] : avtoref. dys. ... kand. nauk z derzh. upr. Nats. akad. derzh. upr. pry Prezydentovi Ukrainy. K. 20 s. [in Ukrainian].

14. Sydorenko P. V. (2012) Kadrova polityka v mistsevykh orhanakh vykonavchoi vlady Ukrainy: sutnist ta tendentsii rozvytku [Personnel policy in local executive bodies of Ukraine]: avtoref. dys. ... kand. nauk z 


\section{Науковий вісник : Державне управління №1 (7) 2021}

derzh. upr. Nats. akad. derzh. upr. pry Prezydentovi Ukrainy. K. 20 s. [in Ukrainian].

15. Surai I. H. (2014) Formuvannia y rozvytok elity v derzhavnomu upravlinni Ukrainy [Personnel policy in local executive bodies of Ukraine]: avtoref. dys. ... d-ra nauk z derzh. upr. Nats. akad. derzh. upr. pry Prezydentovi Ukrainy. K. 36 s. [in Ukrainian].

16. Liderstvo (2014), upravlinska elita v suchasnykh umovakh derzhavotvorennia: naukovo-bibliohrafichnyi. Pokazhchyk [Leadership, management elite in modern conditions of state formation: scientific and bibliographic]. / Viddil informatsiino-bibliotechnoho zabezpechennia. K.: NADU. URL: https://cutt.ly/AjO9CvE [in Ukrainian].

17. Yakubovskyi O. P., Prykhodchenko L. L. (2001) Kadry, elity, liderstvo v derzhavnomu upravlinni : navch.-metod. Posibnyk [Personnel, elites, leadership in public administration]. O.: OF UADU : Optimum. $173 \mathrm{~s}$. [in Ukrainian].

18. Mykhnenko A. M., Honcharuk N. T., Makarenko E. M. (2012) Liderstvo ta upravlinska elita : navch. posib. [Leadership and management elite]. K. : NADU. 291 s. [in Ukrainian].

19. Piren Mariia (2012) Liderstvo: sutnist ta realizatsiia v ukrainskomu suspilstvi [Leadership: Gist and realization in the Ukrainian society] : navch. posib. dlia stud. vyshch. navch. zakl. K. : Universytet "Ukraina". 231 s. [in Ukrainian].

20. Hoshovska V. A. ta in. (2015) Liderstvo v mistsevomu samovriaduvanni [Leadership in local government: words] : slov. terminiv. Kharkiv : Faktor. $155 \mathrm{~s}$. [in Ukrainian].

21. Izha M. ta in. (2013) Liderstvo $v$ systemi derzhavnoi sluzhby [Leadership in the civil service]: navch. posib. Odesa : ORIDU NADU. 130 s. [in Ukrainian].

22. Liderstvo (2012) v derzhavnomu upravlinni [Leadership in public administration] : zb. dop. shchorich. Risheliev. akad. chytan (21-23 veres. 2011 r., m. Odesa). O. 268 s. [in Ukrainian].

23. Tizdeil Dzhon, Khiuz Dzhefr (2013) Efektyvne liderstvo ta menedzhment [Effective Leadership and Management]: prakt. posib. O. : Feniks. 140 s. [in Ukrainian].

24. Lankaster Dzhym (2017). Liderstvo v styli Lean. Shliakh do postiinoho vdoskonalennia vashoho biznesu : [per. $\mathrm{z}$ anhl.] [The work of management: a daily path to sustainable improvement] / Jim Lancaster./. Kyiv : Feniks. 238 s.

25. Adizes Itskhak (2019) Komandne liderstvo. Yak porozumitysia z budyakym menedzherom [Leading the leaders: how to enrich your style of management and handle people whose style is different from yours / Ichak Adizes. Santa Barbara, 2004]. Kyiv : Nash format. 312 s. [in Ukrainian]. 
26. Maksvell Dzhon (2019) 21 bezzaperechnyi zakon liderstva [per. z anhl. T. Frolov; peredm. Stivena R. Kovi]. [The 21 irrefutable laws of leadership: follow them and people will follow you / John C. Maxwell. Nashville, 2007]. 2-he vyd. Kharkiv : Klub Simeinoho Dozvillia, 2019. 319 c. [in Ukrainian].

27. Bizo L., Ibrahimova I., Kikot O., Baran Ye. (2012) ta in. Rozvytok liderstva [Leadership development]. K. : Proekt «Reforma upravlinnia personalom na derzhavnii sluzhbi v Ukraini». $400 \mathrm{~s}$.

28. Bernard M. Bass, Russ Bass (2008) Handbook of Leadership: Theory, Research, and Managerial Applications. URL: https://cutt.ly/OjahBhd (data zvernennia 10.10.2020).

29. Storozhuk R. I. (2017) Stan doslidzhennia problemy liderstva u vitchyznianii ta zarubizhnii literaturi. Derzhava ta rehiony. Seriia Derzhavne upravlinnia.2017. №3. S. 21 - 25. [in Ukrainian].

30. Chernov S. I., Haiduchenko C. O. (2014) Vplyv liderstva na formuvannia ta rozvytok orhanizatsiinoi kultury $\mathrm{v}$ publichnomu upravlinni [Influence of leadership on the formation and development of organizational culture in public administration]. Efektyvnist derzhavnoho

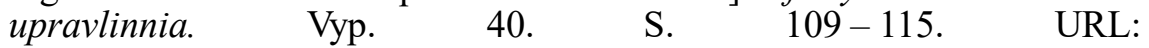
http://nbuv.gov.ua/UJRN/efdu_2014_40_15 (data zvernennia 10.10.2020) [in Ukrainian].

31. Romanovskyi O. H., Hura T. V., Knysh A. Ye., Bondarenko V. V. (2017) Teoriia i praktyka formuvannia lidera [Theory and practice of leadership formation] : navch. posib. $100 \mathrm{~s}$.

32. Fidler F. Pro modeli kerivnytstva [On leadership models]. URL: http://pidruchniki.com.ua/19310710/menedzhment/modeli_keruvannya. (data zvernennia: 10.10.2020).

33. Bozadzhyev V. L. (2015) Polytycheskaia psykholohyia: ucheb. posob. M. 474 s. [in Russian].

34. Jerry Toomer (2018) Craig Caldwell The Catalyst Effect: 12 Skills and Behaviors to Boost Your Impact and Elevate Team Performance. Emerald Publishing Limited. 255 p. 


\title{
CIVIL SERVICE LEADERSHIP PHENOMENON
}

\section{Lytvynovskyi Yevhen, Lytvynovska Iryna}

\begin{abstract}
The phenomenon of leadership has been studied for many years by many scientists. Studies of some of them related to the topic of the article are analysed in it. Given that the nature of the leadership phenomenon is extremely complex, it is individual and social in nature, the article defines that leadership is a unique synergy of: natural-genetic (God-given) inclinations; maternal (paternal) upbringing; favourable social environment (surrounding, including educational, as a value-forming backbone of society); own functionality of the professional's personality. Functionality is determined by acquired experience, consciously or unconsciously formed skills, abilities, and qualities. The article analyses some approaches to defining the phenomenon of leadership. It is determined that the most established theories are charismatic and synthetic theory, "trait theory", as well as situational and behavioural approach. Emphasis is placed on the fact that instrumental and emotional leadership, two important new concepts of leadership - "T-model" and "Leader-catalyst" - are interesting for the civil service. The civil service should be aimed at "the common good, the interests and needs of others and their satisfaction only subject to legal and moral restrictions upholding." The article concludes that the phenomenon of Leadership is a phenomenon generated by a system of informal, unofficial relationships between people. It occurs naturally in any group based on the influence of the personal authority of the leader on the relationships and behaviour of others. The role of the leader arises spontaneously, it is not provided by the staffing schedule of the organization. Leadership is the over competence of the individual, including the leader, which is difficult to measure and difficult to reproduce. A further scientific task is determined by a hypothetical search for a list of personal and professional qualities that make an ordinary person a leader. The question is posed: is there such a genius - a leader (head), on whose activities' study basis it would be possible to determine a repertoire of qualities, the reflection of which in society will help it to get out of the crisis and reach the "era of common good".
\end{abstract}

Key words: leadership phenomenon, civil service, situational and emotional leadership, T-leadership, natural-genetic inclinations, social environment, parental upbringing. 